\title{
Local empowerment through the creation of coastal space?
}

\author{
Jahn Petter Johnsen ${ }^{1}$ and Bjørn Hersoug ${ }^{1}$
}

\begin{abstract}
Developments in national fisheries and marine environmental policies during the last 30 years have changed the relationship between coastal communities and the marine resources that people in these communities traditionally harvested. In Norway, for example, when the state authorities have made decisions to defend what they regard as national interests, the local level has been left with authority over minor issues related to area planning in the coastal zone. Although coastal planning until recently was about sharing fishing areas between different users, we now see a spatial dimension emerging in planning, giving it a much broader scope. The processes of defining spatial properties and creating coastal space as a governable object have the potential to empower local communities. These processes contribute to enhanced local control and improved local participation in the governance of natural resources. In Norway, the 2008 Planning and Building Act strengthened the role of municipalities in local planning. In addition, the application of a new three-dimensional, spatial approach to coastal planning may create opportunities for new control over local resources. In marine spatial planning (MSP) the natural resources are seen as part of coastal spatial properties; thus, governing of sea space implies resource governance. As our examples illustrate, considerable power is associated with the ability to identify and define the properties of coastal space. MSP could become an important tool for controlling local resources, rebuilding collapsed fisheries, and managing them sustainably at the level of municipalities.
\end{abstract}

Key Words: coastal governance; coastal space; marine spatial planning

\section{INTRODUCTION}

During the last 30 years, development of national fisheries and marine environmental policies has changed the relationship between coastal communities and marine resources. Marine resources like fish and other living resources are generally defined as national resources, to be managed centrally by the state.

However, marine spatial planning (MSP) has been identified as a promising tool for improved resource management worldwide (Ehler 2012; Marine Spatial Planning Initiative, http://www. unesco-ioc-marinesp.be/). MSP involves analyzing and allocating parts of the three-dimensional marine space to specific uses, or nonuse, to achieve ecological, economic, and social objectives that are usually specified through a political process (Douvere 2008, Douvere and Ehler 2009). MSP represents a shift from the governance of living and nonliving extractable resources to the governance of the space where the extraction takes place. If spatial planning is delegated to communities and municipalities, this shift may imply new opportunities for more local control over local resources.

In Norway, planning of coastal space is a municipal responsibility and has traditionally taken place inside the "coastal baselines." Coastal baselines are the lines used for measuring the breadth of a state's territorial sea. They are defined either by the low-water line along the coast or, as in Norway, by straight lines between appropriate points on the furthest extension of the low-water line (Office for Ocean Affairs and the Law of the Sea 1989). In Norway, coastal zone planning has gradually expanded from the physical planning of harbor development in the 1980s to planning for different types of use for coastal space today, particularly for aquaculture. The Planning and Building Act of 2008 extended planning responsibilities to include an area up to one nautical mile beyond the baselines, thus bringing Norway in line with the European Union's water framework directive. However, municipalities still plan sea areas on a voluntary basis. Currently, this planning includes biodiversity and a wider range of objectives, quite in accordance with current MSP thinking (Ministry of the Environment 2009), which may give the municipalities considerable power in defining what the coastal space is and how it shall be used. In this article we pose the following question: Can the development from two-dimensional area planning toward MSP give local communities more power over the use of local marine resources?

\section{THEORY AND METHODOLOGY: GOVERNANCE AND GOVERNABLE OBJECTS}

Natural resource governance is based on interventions that regulate human behavior (Berkes 2008). These interventions are defined on the basis of assumptions about how human actions affect nature (Pálsson 2006). Because nature is not directly accessible, it has to be represented through specific governable objects that then become the foundation for defining interventions (Johnsen et al. 2009, Johnsen 2013). Governable objects are constituted when the components and processes in an ecosystem are represented symbolically. Specific techniques are used to translate and assemble the components and processes into bounded, homogenous objects that can be measured, quantified, or modeled in ways that make it possible to create specific intervention mechanisms for governance, as is done with a fish stock. Governable objects are what Mol (2002) calls multiple objects, which are held together by the power of knowledge, science, and practice. Marine planning is a process whereby coastal space becomes framed as a governable object (Johnsen et al. 2014). Coastal space as a governable object is not equal to the undefined natural space, but a translation of an ungovernable complexity into a defined, governable object that can serve as a foundation for governance interventions. In a marine setting this takes place, for example, when a variety of biotic and abiotic components in a specific location are translated into specific spatial properties that can be defined on a map representing the space. Thus, the process is about stabilizing the relations that constitute the multiple objects in a way that makes those object 
Table 1. Overview of the phases for creation of a governance object (after Mol 2002).

\begin{tabular}{lll}
\hline \hline Phase & Actions & Outputs \\
\hline $\begin{array}{l}\text { Coordination of relevant actors and } \\
\text { contributors }\end{array}$ & $\begin{array}{l}\text { Data collection methods, coordination, } \\
\text { calibration and conceptualization, definition } \\
\text { of the objects }\end{array}$ & $\begin{array}{l}\text { Establishment of a common language with } \\
\text { definitions, concepts, and categories } \\
\text { Consensus about definition and } \\
\text { categorization of the objects }\end{array}$ \\
$\begin{array}{ll}\text { Distribution of power and responsibilities } \\
\text { Inclusion, stabilizing the network }\end{array}$ & $\begin{array}{l}\text { Defining and selecting problems, solutions, } \\
\text { and indicators, establishing relationships and } \\
\text { allocating responsibilities }\end{array}$ & $\begin{array}{l}\text { Defined roles and responsibilities in relation } \\
\text { to constitution of governance objects, defined } \\
\text { space for each actor, choice of instruments } \\
\text { (maps, quality assurance, and validation) }\end{array}$ \\
& $\begin{array}{l}\text { Knowledge definition and authorization, } \\
\text { establishment of relations between properties, } \\
\text { actors, and object } \\
\text { Evaluation and modification of instruments, } \\
\text { production of official maps } \\
\text { and stabilized as a complex and multiple } \\
\text { entity. Space, spatial properties, spatial } \\
\text { representation, and practices will exist side by } \\
\text { side and in relationship to each other } \\
\text { The multiple object is controlled and managed } \\
\text { by the interests that are defined as "within" }\end{array}$ \\
& & $\begin{array}{l}\text { through the selected and agreed tools, like the } \\
\text { map }\end{array}$ \\
\hline
\end{tabular}

(s) durable (Callon and Latour 1981). A multiple object is a network of relationships among many different types of actors, people, organizations, natural elements, images, and ideas, all playing different roles in constituting the object.

To view governable objects as constructed is an actor-network approach. However, we are particularly inspired by Annemarie Mol and her book, The Body Multiple: Ontology in Medical Practice (2002), in wich she demonstrates how a disease becomes a treatable object within the framework of a modern hospital. Through a similar process, MSP contributes to the constitution of coastal space as a governable object. The process we describe takes place in three partly overlapping phases: (1) a coordination phase, during which a common language, categories, and concepts are established; (2) a distribution phase, during which the roles, responsibilities, indicators, and solutions to coastal management problems are defined; and (3) an inclusion phase, during which the multiple elements, especially from the distribution phase, become related and bound together into a material multiple object inside a specific framework that makes management possible (see Table 1).

\section{METHODS}

This article is based on qualitative data collected in an interdisciplinary research project called Integrated Coastal Management, on which 11 Norwegian research institutes collaborated. The main outcome from this project is a book on various aspects of Norwegian coastal planning (Hersoug and Johnsen 2012). In addition to the book, several more technical publications have been produced. The data used in this article were derived from extensive fieldwork, interviews with planners and a number of key stakeholders, reviews of public documents, and analyses of the public debate regarding the use of coastal space. Because fishers' knowledge and biodiversity have become important issues in contemporary Norwegian coastal planning, we have regarded insight into the methods used to collect fishers' knowledge and to map biodiversity as crucial to understanding how coastal space is constituted as a governance object.
Consequently, we did a thorough analysis of the manuals for fisheries data collection from the Directorate of Fisheries (DoF) and for biodiversity mapping from the Norwegian Directorate for Nature Management (Norwegian Directorate for Nature Management 2007, Directorate of Fisheries 2008, 2010a, b).

\section{RESULTS: THE CREATION OF COASTAL SPACE}

Establishing a coordination framework: municipal area planning When the Building Act was introduced in Norway in 1965, it was as an important element in nationwide physical and economic planning, which should have led to comprehensive land use plans and revolving investment programs for geographical units of different sizes. The system was based on coordinating all planning within sector organizations at state, county, and municipality levels (Hersoug 2012). In reality, such coordination was more complicated than anticipated. Consequently, coastal planning and the use of sea areas did not receive much attention, particularly because at that time the marine activities of fishing and sea transport were effectively managed by the Ministry of Fisheries, a ministry that considered itself an advocate of these sector interests at the national level and wanted as little interference as possible from other administrative levels and bodies. However, within a short time the rapid expansion of the aquaculture industry made it necessary to establish a system that could solve some of the conflicts related to the aquaculture industry's permanent occupation of a former open coastal space. With the revision of the Planning and Building Act (PBA) in 1985, coordinating efforts were even more strongly emphasized because the act aimed to coordinate all aspects of development in the local communities (Bukve 1993). At sea, this involved not only the coordination of fishing and aquaculture, but also sea transport, recreational use, tourism, and conservation. The revision of the PBA in 1985 gave the municipalities this responsibility. Even if the PBA at the time only encompassed harbor areas, the municipalities had to solve local area conflicts between fisheries and aquaculture. Thus, even though the Ministry of Fisheries was responsible for fisheries and aquaculture management, the 
allocation of coastal space now became a municipal task. This division of responsibility was formalized in 1989, when the municipalities got the right to plan the sea areas inside baselines, thus expanding the planning area to some $100,000 \mathrm{~km}^{2}$ nationally. Although planning at sea was not made mandatory, this formalization gave the municipalities authority to organize coastal planning processes. Based on plan proposals from the municipal administration, the politically elected municipal councils could make binding decisions for use of costal space. According to the PBA, an approved spatial plan is a legally binding document for the municipality and other authorities if it contains a map that displays the allocation of areas for different uses.

Within the aquaculture sector there were serious coordination problems: licenses were granted by the DoF under the Ministry of Fisheries, discharge permits were granted by the state county authority under the Ministry of the Environment, and animal health and food safety were managed by the Norwegian Food Safety Authority under the Ministry of Agriculture and the Ministry of Health. This fragmentation of responsibilities placed the municipalities in the middle of jurisdictional power struggles between different ministries and state authorities (Sandersen and Nicolaisen 2007).

\section{The struggle for distribution: from area planning to spatial planning}

The article "Coastal planning on the Atlantic fringe, north Norway: the power game" (Bennett 2000) gives a vivid description of coastal planning in the 1980s. Bennett demonstrates how coastal planning became established as a new activity in a struggle with established sector organizations within fisheries and environmental management agencies that were rather unwilling to redistribute power and influence to the level of municipal planning. Coastal zone planning in Norway was described as a battleground for sector interests at the state level (Hovik and Stokke 2007a, b), because the municipalities started to see planning as a tool to get better control of local resources. Since that time, development has been less conflict ridden, and redistribution of power and a new division of labor have evolved. In accordance with more recent governance principles, planning has become a process for negotiation among stakeholders (Hersoug 2012). The different sector organizations know more or less the position of the others, and a number of appeal cases have established norms for what are acceptable planning practices in terms of allocating space for different activities. In Mol's (2002) case, the hospital, the distribution phase was important for avoiding open conflicts; however, in coastal zone planning, the distribution phase in the planning process is an arena for displaying and solving conflicts among various stakeholders and agencies (Johnsen and Hersoug 2012).

A key challenge in coastal planning at the local level has been the tensions between national and local concerns. Local politicians and planners say they feel they are "conserved to death," implying that many attempts to create local employment are effectively stopped by national conservation measures. The municipalities are in some cases overruled by state institutions, headed by the Ministry of the Environment. As demonstrated by Buanes (2008) the coastal conservation plan in Nordland County in northern Norway initiated by the Ministry of the Environment met strong criticism from the local stakeholders and it took 10 years to finalize the plan. In 2009, a nationwide process regarding marine protected areas started, a process that is going to influence a large number of municipalities, including some of our case communities (Norwegian Directorate for Nature Management 2009). Even if the guidelines stress that conservation is not going to affect traditional use, such national plans may not necessarily be in accordance with local priorities. The experience so far in Norway has been that national plans incorporate to a very limited degree what municipalities need for local use and development, and the municipalities respond with requests for the acquisition of more room to maneuver to integrate some of the national priorities into their local plans.

However, the conflict is not only about national versus local interests. In one of our case studies (Altafjord), local conflicts about the use of sea space have increased. In the past, conflicts could be discussed and solved locally as long as aquaculture was primarily carried out by local entrepreneurs who offered local employment. Today, however, the owners are large multinational companies, and they cannot draw on the same goodwill as local owners. Fishers and recreational users must now relate to large companies and not to their neighbors, as was previously the case. They tend to see their claims and demands as being just as important as those put forward by the aquaculture companies, and local tolerance of inconveniences caused by the companies has clearly diminished. The less the municipality receives in return for its work to create sites for aquaculture, the greater the potential for conflict. The benefits of new employment and added tax income have to be weighed against the costs of a reduced fishery, pollution from aquaculture, and spatial limitations imposed on other activities such as recreational fishing and tourist activities. Local planners now face increased numbers of concerned stakeholders and new challenges in terms of expectations and requirements from the state, which all combine to lead to more complex planning procedures (Hersoug 2012).

Moreover, a common denominator for coastal planning in Norway so far has been that the different area classifications have been poorly adjusted to the special challenges related to planning at sea. Because of the historical roots of the planning initiative in land-based area planning, it has primarily used categories best suited for two-dimensional surface area planning. Planning at sea, however, requires in principle a three-dimensional and dynamic approach because (1) activities like aquaculture and the harvesting of mobile marine resources affect the water column and (2) the use of coastal areas may change over time. Important fishing areas, for example, may change over time because of natural variations.

Compared with the old PBA, the new PBA of 2008 has a broader scope and increased ambitions because of a steady stream of new goals and interests that need to be taken care of and coordinated (Ministry of the Environment 2009). The new act has also strengthened the municipalities' position and added to their planning responsibilities. Ambitions and responsibilities have increased for coastal planning in particular, not only because conflicting interests need to be harmonized and coordinated but also because planning should contribute to sustainable development; that is, planners will have to consider more carefully user impact and ecosystem processes. Norway has implemented 
the European Union's Water Framework Directive for water quality and has also started an initiative to map biodiversity along the coast. Consequently, planning cannot be restricted only to the local level because water quality, mapping of biodiversity, and efficient use of space all have to be dealt with either in collaboration with other municipalities or on a regional or central level (Norwegian Directorate for Nature Management 2007).

Because of this broadened scope, central authorities are trying to encourage coastal zone planning on a regional or county level, covering several municipalities. Although until 2009 the regional plans could not be made statutory law, planning on a higher level can now contribute to better coordination. Hovik and Stokke $(2007 a, b)$ have found that the success of such an approach depends to a large degree on how the planning agencies organize the planning process and on the participation of stakeholders. The experiences from the three counties they studied demonstrate that stable networks meeting to discuss different issues may over time create confidence at the local, i.e., municipal, level, which in turn can be used to develop joint management area rules and priorities. Power games still are going on, but steps have been taken to create better coordination and clearer demarcation between different areas of responsibility.

To sum up, the new PBA and the recent development of Norwegian coastal planning are now going more in the direction of three-dimensional MSP. This development opens new opportunities for municipalities to create their own coastal space. This, in turn, increases possibilities to incorporate local fishing knowledge.

\section{Inclusion: how coastal space gets properties through sampling and mapping}

Until recently, Norwegian coastal planning was largely about defining appropriate localities for aquaculture to the neglect of other concerns; the coastal areas were, to some extent, regarded as empty. A spin-off from research that sought new approaches to fisheries management changed this situation. In the $1990 \mathrm{~s}$, a social scientist and a fisheries biologist identified 44 local cod spawning grounds based on interviews with active fishers (Maurstad et al. 1992, Maurstad and Sundet 1998, Maurstad 2000, 2002, Solås and Hersoug 2012). Because of concerns about ethical considerations, they decided not to publish the results (Maurstad 2002). However, the project introduced a methodology and concepts that represented a link to an emerging field of research: the mapping of local ecological knowledge/fishers' ecological knowledge. In the wake of this work, users' knowledge (whether called local ecological knowledge or fishers' ecological knowledge) has become an accepted concept in Norwegian science and management. It is now well documented that fishers possess substantial knowledge about fish behavior such as spawning and breeding areas, fishers' behavior, and the use of sea areas by different ethnic groups (Davis and Wagner 2003, Murray et al. 2006, Berkes 2008, Murray et al. 2008, Brattland and Nilsen 2011). This knowledge has become an important element of Norwegian coastal planning (Johnsen et al. 2014), and is a key element in identifying local stocks of the threatened coastal cod.

Maurstad and Sundet did not entirely start from scratch. The DoF, which is the technical and administrative body responsible for fisheries and coastal management in Norway, was involved in survey projects to map fishing activities along the coast in the early 1980s. The purpose was to identify fishing grounds and spawning and nursery areas for fish to avoid conflicts with the fishing industry related to locating aquaculture farms in such areas (Directorate of Fisheries 2008). In 2003, the DoF created a Geographical Information Systems (GIS) database for key resources and fishing activities in the coastal zone. At the same time, the Institute for Marine Research (IMR) was assigned responsibility for mapping biological diversity in Norway (Norwegian Directorate for Nature Management 2007). The mapping was conducted by staff at DoF's regional offices through interviews with fishers and research cruises carried out by the IMR. Interesting enough, there is correspondence between the maps produced on the basis of the different data (Solås and Hersoug 2012, Johnsen et al. 2014).

After data collection, the key activities in this process were digitization of the data and transfer of the knowledge onto maps. Latour (2005) describes this transfer as "the inscription" of the collected information into a stabilizing device, the map. When the various fishing activities, areas, and organisms are placed on a map, a particular coastal space consisting of sea bed, water column, and surface is constructed and stabilized, and becomes firmly anchored to the real landscape and seascape. The different zones in the map become a representation of spatial properties, and the space becomes a governable object. Maps produced by DoF and IMR through this process are used as a foundation for other maps such as municipal planning maps, with clear legal consequences. However, even though the maps fix some activities and properties of the space in question in a way that makes these properties replicable, modern technology also enables the maps to be rendered dynamic. Maps not only depict the properties of the coastal space, but also are actually used to construct and define space and spatial properties (Smith and Brennan 2012). As an example, the Norwegian maps of the coastal zone, either sector bodies' national maps or municipal land use maps, are continuously updated. Initially the maps contained only shipping lanes, fishing grounds, spawning areas, and fish farms; now, information about the flora and fauna, cultural heritage (shipwrecks), proposed marine protected areas, and so forth are being added (Johnsen and Hersoug 2012). Currently, the coastal zone is filled up with objects that all relate to each other as coastal zone properties while contributing to development of the coastal zone as a governable object.

Despite this dynamism, flexible indicators appear as objective and fixed when they are used to identify an activity that is inscribed onto a map. Ignoring their inherent dynamism may result in some areas being considered less important for the fisheries and therefore easily allocated to, for example, the wind power industry, which is able to specify very precisely the value that can be generated in a specific area. On the other hand, GIS technology makes it easier for fishers and other groups to provide the necessary information. They do not have to rely any longer on institutions like DoF and IMR for presentation of the knowledge. Despite the fact that indicators may change over time, the maps represent a form of semiobjective knowledge that is difficult to challenge if other users are not able to present the same type of information, that is, activities put down on a map.

A recent example from Norway illustrates the dynamics of the marine environment and fishers' knowledge of it. Lofoten and 
Vesteraalen in northern Norway are the main spawning and fishing areas for the northeast arctic cod stock, which is by far the most important coastal fishery resource in Norway. In 2010, a map based on satellite tracking of vessels more than 15 meters in length showed that the fishing activities off the Lofoten and Vesteraalen area were of minor importance. These maps were used in the discussion about opening the area for seismic surveys. However, even this relatively precise indicator, based on satellite tracking of vessels, was rejected as unreliable because when the Norwegian Coastal Fishermen's Association included data for all vessels less than 15 meters in length, based on detailed surveys of the coastal fleet, a very different picture emerged. The continental shelf outside Lofoten and Vesteraalen turned out to be one of the most important fishing areas in Norway. Coastal fishers in this case produced a new map based on different and more detailed information, which added more properties to the area. This shows that maps are not neutral administrative tools but dynamic instruments that can be used strategically, in this case by the fishers, to add new properties to the coastal space (Johnsen and Hersoug 2012, Johnsen et al. 2014). The maps are indeed performative, participatory, and political (Crampton 2009).

\section{DISCUSSION: SPATIAL PLANNING AS A CONSTITUENT OF COASTAL SPACE}

Governance is impossible without stable governable objects. Processes and activities taking place inside a coastal planning framework in Norway have coordinated actors and activities, established a common language and rhetoric, distributed responsibilities, and included and excluded participants and knowledge. The processes and activities have followed the phases in Table 1 and have resulted in the creation of coastal space as a governable object. Through these processes and activities, the coastal space becomes defined and filled with properties and interests. The Norwegian coastal space has been a source of food, a site for recreation and aquaculture, shipping lanes, a dumping ground, a natural symbol, a site of beautiful views, ports, and much more. Activities such as commercial fishing, aquaculture, shipping, recreational fishing, and diving encompass practical uses and symbolic meanings for the users and the public in general. Through the process we have described, mapping spatial properties contributes to changing the two-dimensional area into a three-dimensional space, representing both natural properties, such as valuable or threatened species and spawning grounds, and socioeconomic and cultural properties, such as fishing grounds and use by different ethnic groups. Hence, the activities taking place give a particular governable identity to the marine space, but the users have not necessarily had one clear opinion about coastal space as something that can or has to be managed or governed.

When the properties are digitized and mapped, coastal space is stabilized in the form of a more robust governance object. However, new GIS technology and digital chart systems like the Olex make it possible to continue adding new properties to a coastal space. Through this kind of mapping, the practices and understandings of the users may become more prominent, not only in the process of data collection but also in the interpretation of data because new GIS and digital chart tools actually integrate the scientific and the practical world in new ways. Such integration may have an impact on what kinds of knowledge will be used in future planning and may also influence the division of labor between managers, politicians, and stakeholders. With this tool, municipalities can now collaborate with their public in constructing marine space. Formerly centralized knowledge production can become decentralized.

The process described in this study is about how a network of actors, in this case DoF, IMR, municipalities, fishers, and others, through the help of specific instruments like manuals for data sampling, charts, and GIS tools have come together to identify and define formerly unknown, at least to most people, spatial properties. A municipality alone or in collaboration with others can use these properties to integrate their coastal space into their spatial planning. In the Astafjord project in northern Norway, 12 municipalities, the county administration, the Geological Survey of Norway, and commercial enterprises have collaborated on a mapping project of a fjord system to produce better knowledge for coastal governance (Astafjordprosjektet http://www. astafjordprosjektet.com/). In mid-Norway, 11 municipalities and the county administration collaborated on a common spatial plan for the region (Kysten er klar http://kystenerklar.no/); and in Tvedestrand in southern Norway, the Ministry of Fisheries and Coastal Affairs has confirmed the establishment of a marine protected area inside Tvedestrand municipality's coastal zone after a process in which the IMR and the Tvedestrand municipality were the central partners (Ministry of Fisheries and Coastal Affairs 2012).

Through coordination, distribution, and inclusion, coastal space has emerged as a multiple object consisting simultaneously of many features, characteristics, and meanings (Mol 2002). As demonstrated through a study of fishing off the northeast coast of the United States, mapping of activity and GIS tools can also be used to explore who fishes where and on which fishing grounds the various fishing communities are most dependent (St. Martin and Hall-Arber 2008). That study is similar to the DoF survey: through a combination of interviews and plots on a map that were later calibrated and assembled into a database and processed into digital maps, these researchers were able to show which fishing grounds are important for different communities. With use of GIS, St. Martin and Hall-Arber (2008) showed that the sea consists of more than catch areas; they identified relations between specific fishing grounds and onshore communities: sea space became linked to the land. In addition to their economic importance, these fishing grounds have meaning and cultural significance for onshore communities. Others have used similar approaches to map and interpret Sami fishing space in northern Norway (Brattland and Nilsen 2011). In all cases local economy and culture are relevant components.

\section{CONCLUSION: EMPOWERED MUNICIPALITIES}

Both the fishing industry and the aquaculture industry strongly believe that the state shall manage crucial resources for the industries at a national level. Although the living resources and local fisheries now are the responsibility of the Ministry of Fisheries and Industry and its directorate (DoF), the spatial responsibility is at the municipal level. Thus, because the management responsibility for coastal space is at the municipal level and because this space as an management object is constructed through the steps described in Table 1, the focus on natural resource values, vulnerable resources, and relationships to habitats gives municipalities a new option in the choice of tools 
with which to protect coastal space that is particularly important for local activities as well as for local fish stocks. The diverse forms of knowledge required to produce a multiple coastal space involve many players, and all have a legitimate right to participate. The power to create the legally binding document based on all this information, the map, has been given to the municipality. Even if a municipal plan cannot regulate fishing output, it can under certain conditions have an impact on how and where to fish. With regard to aquaculture the situation is different; fish farms have to be placed where the municipality wants them. In traditional area planning, the map represented an allocation of sea surface to different interests. The maps of today are more complex, representing both biophysical spatial properties and relations between space and interests. Thus, the new PBA and the progress toward locally controlled MSP have opened new opportunities for Norwegian municipalities to acquire a more powerful position in terms of defining their own marine space and indirectly to participate in governing marine resources, hopefully in cooperation with other municipalities, because marine ecosystems normally span the marine space of several municipalities. If local fisheries take place inside the area delimited by one nautical mile from the baseline, municipalities can, through their spatial planning, create alliances and collect knowledge that make it possible to put restrictions on activities that can destroy spawning grounds, occupy fishing grounds, or impact the ecosystem in ways that may hamper positive development in local fisheries. The municipalities become the central points for coastal governance in Norway, not only in terms of legal rights and responsibility but also because they can organize and coordinate the relationships among stakeholders, selecting what knowledge they want to use and setting priorities. In the end, the result will depend critically on the capacity and capability of municipalities to fill this role and to perform this new type of planning well.

Responses to this article can be read online at: http://www.ecologyandsociety.org/issues/responses. $\mathrm{php} / 6465$

\section{Acknowledgments:}

The Integrated Coastal Management project was funded by the Research Council of Norway ( $R C N$ ) and the Norwegian Seafood Research Fund. The writing of this article was also supported by a mobility grant from the Aquaculture program in the RCN and by the Faculty of Biosciences, Fisheries and Economics at the University of Tromso. The authors want to thank the informants for sharing their knowledge with us. Thanks also to the two anonymous reviewers for their comments and to Barbara Neis, Rosemary Ommer, Glen Smith, and Ann-Magnhild Solås for comments and editing.

\section{LITERATURE CITED}

Bennett, R. G. 2000. Coastal planning on the Atlantic fringe, north Norway: the power game. Ocean \& Coastal Management 43(10-11):879-904.
Berkes, F. 2008. Sacred ecology. Second edition. Routledge, New York, New York, USA.

Brattland, C., and S. Nilsen. 2011. Reclaiming indigenous seascapes. Sami place names in Norwegian sea charts. Polar Geography 34(4):275-297. http://dx.doi.org/10.1080/1088937X.2$\underline{011.644871}$

Buanes, A. 2008. Nasjonal politikk utfordres en studie av kystverneplanprosessen $i$ Nordland 1994-2002. Universitetet i Tromsø, Det samfunnsvitenskapelige fakultet, Tromsø, Norway.

Bukve, O. 1993. Kommunal forvaltning og planlegging. Samlaget, Oslo, Norway.

Callon, M., and B. Latour. 1981. Unscrewing the big Leviathan: how actors macrostructure reality and how sociologists help them do so. Pages 277-303 in K. Knorr-Cetina and A. V. Cicourel, editors. Advances in social theory and methodology: toward an integration of micro and macro sociologies. Routledge and Kegan Paul, Boston, Massachusetts, USA.

Crampton, J. W. 2009. Cartography: performative, participatory, political. Progress in Human Geography 33(6):840-848. http://dx. doi.org/10.1177/0309132508105000

Davis, A., and J. R. Wagner. 2003. Who knows? On the importance of identifying "experts" when researching local ecological knowledge. Human Ecology 31(3):463-489. http://dx.doi. org/10.1023/A:1025075923297

Directorate of Fisheries. 2008. Retningslinjer for innsamling, registrering, verdivurdering og offentliggjoring av fiskeridata. Anbefalinger fra utvalget for kystnare fiskeridata [Proposal for a manual for collection of fisheries data]. Rapport lager til internt bruk i Fiskeridirektoratet. Directorate of Fisheries, Bergen, Norway.

Directorate of Fisheries. 2010a. Veiledning for innsamling av kystncere fiskeridata. Utarbeidet av arbeidsgruppen for oppfolging av utvalget for kystnore fiskeridata [Manual for collection of fisheries data]. Directorate of Fisheries, Bergen, Norway.

Directorate of Fisheries. 2010b. Veiledning i intervjuteknikk ved registrering av kystncere fiskeridata. Vedlegg til veiledning for innsamling av kystnare fiskeridata [Appendix to manual, guidelines for how to conduct interviews]. Directorate of Fisheries, Bergen, Norway.

Douvere, F. 2008. The importance of marine spatial planning in advancing ecosystem-based sea use management. Marine Policy 32(5):762-771. http://dx.doi.org/10.1016/j.marpol.2008.03.021

Douvere, F., and C. N. Ehler. 2009. New perspectives on sea use management: initial findings from European experience with marine spatial planning. Journal of Environmental Management 90(1):77-88. http://dx.doi.org/10.1016/j.jenvman.2008.07.004

Ehler, C. N. 2012. Perspective: 13 myths of marine spatial planning. Marine Ecosystems and Management 5(5):5-7.

Hersoug, B. 2012. Kampen om plass på kysten - en historisk skisse. Pages 18-39 in B. Hersoug and J. P. Johnsen, editors. Kampen om plass på kysten: interesser og utviklingstrekk $i$ kystsoneplanleggingen. Universitetsforlaget, Oslo, Norway. 
Hersoug, B., and J. P. Johnsen. 2012. Kampen om plass på kysten: interesser og utviklingstrekk $i$ kystsoneplanleggingen. Universitetsforlaget, Oslo, Norway.

Hovik, S., and K. B. Stokke. 2007a. Balancing aquaculture with other coastal interests: a study of regional planning as a tool for ICZM in Norway. Ocean \& Coastal Management 50 (11-12):887-904. http://dx.doi.org/10.1016/j.ocecoaman.2007.05.003

Hovik, S., and K. B. Stokke. 2007b. Network governance and policy integration - the case of regional coastal zone planning in Norway. European Planning Studies 15(7):927-944. http://dx.doi. org/10.1080/09654310701356647

Johnsen, J. P. 2013. Is fisheries governance possible? 11 February. Fish and Fisheries. http://dx.doi.org/10.1111/faf.12024

Johnsen, J. P., and B. Hersoug. 2012. Når alt henger sammen med alt — et teoretisk rammeverk for å studere kystsoneforvaltning. Pages 40-57 in B. Hersoug and J. P. Johnsen, editors. Kampen om plass på kysten: interesser og utviklingstrekk $i$ kystsoneplanleggingen. Universitetsforlaget, Oslo, Norway.

Johnsen, J. P., B. Hersoug, and A.-M. Solås. 2014. The creation of coastal space-how local ecological knowledge becomes relevant. Maritime Studies 13(2). http://dx.doi.org/10.1186/2212-9790-13-2

Johnsen, J. P., P. Holm, P. Sinclair, and D. Bavington. 2009. The cyborgization of the fisheries: on attempts to make fisheries management possible. Maritime Studies 7(2):9-34. [online] URL: http://munin.uit.no/bitstream/handle/10037/2459/article.pdf?sequence=1

Latour, B. 2005. Reassembling the social: an introduction to actornetwork-theory. Oxford University Press, Oxford, UK, and New York, New York, USA.

Maurstad, A. 2000. Trapped in biology: an interdisciplinary attempt to integrate fish harvesters' knowledge into Norwegian fisheries management. Pages 135-152 in B. Neis and L. Felt, editors. Finding our sea legs: linking fishery people and their knowledge with science and mangement. Iser, St. John's, Newfoundland and Labrador, Canada.

Maurstad, A. 2002. Fishing in murky waters - ethics and politics of research on fisher knowledge. Marine Policy 26(3):159-166. http://dx.doi.org/10.1016/S0308-597X(01)00045-8

Maurstad, A., P. Holm, and B. Hersoug. 1992. Fra økonomisk rasjonalitet til okologisk kompetanse: samfunnsvitenskapelig forskning om lokale fiskerisamfunn. Norges fiskerihøgskole, Tromsø, Norway.

Maurstad, A., and J. H. Sundet. 1998. Den usynlige torsken forsker- og fiskerkunnskap om lokale fiskeressurser [The invisible cod-scientist and fishermen's knowledge about local fish resources]. Pages 9-25 in B. K. Sagdahl, editor. Fjordressurser og reguleringspolitikk. En utfordring for kystkommuner? Kommuneforlaget, Oslo, Norway.

Ministry of the Environment. 2009. Ikraftsetting av ny plandel $i$ plan og bygningsloven [Implementation of Plan and Building Act of 2008]. Rundskriv T-2/09. Ministry of the Environment, Oslo, Norway.

Ministry of Fisheries and Coastal Affairs. 2012. Forskrift om bevaringssoner $i$ Tvedestrand kommunes sjøområder, Aust-Agder.
Ministry of Fisheries and Coastal Affairs, Oslo, Norway. [online] URL: http://lovdata.no/dokument/FV/forskrift/2012-06-20-617

Mol, A. 2002. The body multiple: ontology in medical practice. Duke University Press, Durham, North Carolina, USA. http:// dx.doi.org/10.1215/9780822384151

Murray, G., B. Neis, and J. P. Johnsen. 2006. Lessons learned from reconstructing interactions between local ecological knowledge, fisheries science, and fisheries management in the commercial fisheries of Newfoundland and Labrador, Canada. Human Ecology 34(4):549-571. http://dx.doi.org/10.1007/s10745-006-9010-8

Murray, G., B. Neis, C. T. Palmer, and D. C. Schneider. 2008. Mapping cod: fisheries science, fish harvesters' ecological knowledge and cod migrations in the Northern Gulf of St. Lawrence. Human Ecology 36(4):581-598. http://dx.doi. org/10.1007/s10745-008-9178-1

Norwegian Directorate for Nature Management. 2007. Kartlegging av marint biologisk mangfold. [Manual for mapping of biodiversity]. DN-håndbok 21-2001, revidert 2007. Norwegian Directorate for Nature Management, Trondheim, Norway.

Norwegian Directorate for Nature Management. 2009. Nasjonal marin verneplan [National Marine Protection Plan]. Norwegian Directorate for Nature Management, Trondheim, Norway.

Office for Ocean Affairs and the Law of the Sea. 1989. The Law of the Sea. Baselines: an examination of the relevant provisions of the United Nations Convention on the Law of the Sea. United Nations, New York, USA.

Pálsson, G. 2006. Nature and society in the age of postmodernity. Pages 70-93 in A. Biersack and J. B. Greenberg, editors. Reimagining political ecology. Durham University Press, Durham, North Carolina, USA.

Sandersen, H., and O. Nicolaisen. 2007. Fra kystallmenning til kolonihage - havbruk og arealbruk i tre nordlandskommuner. Pages 173-193 in G. Rusten and B. Aarset, editors. Havbruk akavkultur på norsk. Fagbokforl, Bergen, Norway.

Smith, G., and R. E. Brennan. 2012. Losing our way with mapping: thinking critically about marine spatial planning in Scotland. Ocean \& Coastal Management 69:210-216. http://dx. doi.org/10.1016/j.ocecoaman.2012.08.016

Solås, A. M., and B. Hersoug. 2012. Fra fisker, via byråkrat og forsker til plan - om bruken av lokal kunnskap i arealplanprosessen. Pages 138-158 in B. Hersoug and J. P. Johnsen, editors. Kampen om plass på kysten: interesser og utviklingstrekk $i$ kystsoneplanleggingen. Universitetsforlaget, Oslo, Norway.

St. Martin, K., and M. Hall-Arber. 2008. Creating a place for "community" in New England fisheries. Human Ecology Review 15(2):161-170. 